\title{
Malignant T Cell Amplified Sequence 1
}

National Cancer Institute

\section{Source}

National Cancer Institute. Malignant T Cell Amplified Sequence 1. NCI Thesaurus. Code C33913.

Malignant T cell amplified sequence $1(181 \mathrm{aa}, \sim 21 \mathrm{kDa}$ ) is encoded by the human MCTS1 gene. This protein plays a role in both the progression of the cell cycle and the response to DNA damage. 